\title{
First Report on Characterization of Citrus Disease Causing Bacteria and Related Phages Isolated in Pakistan
}

\author{
Saadia Naseem*, Hamid Ali Shah and Zahid Ali \\ Department of Biosciences, Academic Block III, G41 COMSATS Institute of Information Technology (CIIT) Park Road, Chak \\ Shahzad, Islamabad 44000, Pakistan \\ *For correspondence: saadia.naseem@comsats.edu.pk
}

\begin{abstract}
Bacteriophages that infect specific bacteria are relatively common. Specific bacteriophages are proving to be the potential alternate to conventional bactericides used to combat certain phytopathogens that are ruining economically significant fruit crops. This study aimed to isolate and characterize the citrus disease causing bacteria and associated bacteriophages analyzing their ability to impact these specific bacteria. Morphological, biochemical and molecular characterization of seed bacteria were performed and identified isolates were subjected to custom sequencing of partial 16S ribosomal DNA to understand their phylogeny. The morphological characteristics of bacterial strains were Gram-negative rods that grew as obligate aerobes on YPGA medium. Results of biochemical analysis showed that the bacterial strains were oxidase negative and catalase positive. Phage screening and isolation was done by co-culturing the phage and host bacteria. The isolated phages were characterized by plaque assay, spot assay and broth clearance of bacterial cultures. The effect of these phages on bacterial virulence was evaluated by infecting citrus leaves with bacterial strain and subsequent application of phage suspension. (C) 2017 Friends Science Publishers
\end{abstract}

Keywords: Bacteriophage; Biological control; Citrus bacterial disease; Pakistan

\section{Introduction}

Citrus is one of the most important commercial and nutritional crops of the world. Pakistan an ideal climate and temperature suitable for cultivating almost all types of citrus. Pakistan annually produces 13.7 million tons of fruits and vegetables (PHDEB, 2008) and stands at $12^{\text {th }}$ position among citrus producing and exporting countries. It is the top producer of kinnow in the world. However, average citrus yields in Pakistan are much less than its potential yield, due to a number of cultural and environmental factors and prevalence of infectious diseases. Asiatic citrus canker also known as canker A, cancrosis A or true canker, is a bacterial disease (Vauterin et al., 1995). Asiatic canker is known to be the most devastating disease affecting citrus production and reducing local and international markets. The causative agent is a Gram-negative rod-shaped bacterium with single polar flagellum (Wakimoto, 1967) generally from Xanthomonas spp. (Vauterin et al., 1995). Symptoms appear as erumpent lesions on fruit, foliage and stem. The lesions expand over time and their color changes from light tan to brown. Subsequently water soaked margins appear around the lesions frequently surrounded by chlorotic halo (Gottwald et al., 2002). The center of the lesion becomes raised and corky and the touch of the lesion feel like sand paper (Stall and Civerolo, 1991). Eventually the lesions form a crater like appearance and in some hosts they fall out leaving a shot-hole appearance. Severe disease can cause defoliation, dieback and fruit drop (Gottwald et al., 2002).

Several strategies have been adopted for the treatment, control and eradication of the disease. These include strict quarantine measures to avoid the introduction of the disease, uprooting and burning all the infected grooves, then planting canker-free nursery stock, establishing wind breaks and fences to restrict the spread of infection and preventive sprays of copper-based bactericides. However, these strategies are not feasible in all citrus growing regions of the world. There is also growing concern of copper resistant $\left(\mathrm{Cu}^{\mathrm{r}}\right)$ strains in phytopathogens (Canteros, 2010), soil contamination from extended heavy use of copper compounds (Behlau et al., 2011) and phytotoxicity due to accumulation of ionic copper. Hence, Environmental protection concerns and food safety necessitates the development of safe, more specific and environment friendly bactericide. Because of the promising results in human and veterinary infections, bacteriophages got interest in plant diseases as well. Phages against phytopathogens were discovered a century ago but only recently has there been scientific evaluation of their use as biological control agents. OmniLytics Inc. is the first company who received the registration from the U.S. Environmental Protection Agency for its first bacteriophage-based product, 
“AgriPhage” (EPA Reg. No. 67986-1). Agriphage is used for the treatment of bacterial spot caused by Xanthomonas campestris pv. vasicatoria and bacterial speck caused by Pseudomonas syringae pv. tomato in tomatoes and pepper. Other diseases for which phage therapy is in trial include fire blight caused by Erwinia amylovora (Schnabel and Jones, 2001) and soft rot and stem rot in Chinese cabbage, potato, and tomato plants caused by Pectobacterium carotovorum subsp. carotovorum. (Lim et al., 2013). Several lytic phages against Ralstonia solanacearum that causes bacterial wilt in tomato have been tested in recent years. These phages were used as prophylactics by applying them to seeds before sowing (Fujiwara et al., 2011).

Bacteriophages associated with citrus canker causing bacteria were first isolated and studied for its host specificity in India (Uppal, 1933). Balogh et al. (2008) carried out greenhouse and nursery trials and used Duncan grape fruit plants, which are highly susceptible to specific pathogenic bacteria to evaluate the suppression of citrus canker disease in the presence of high titers $\left(10^{8}-10^{9} \mathrm{PFU} / \mathrm{mL}\right)$ of phages. The results were promising as phage application significantly reduced disease severity. Most recently a well characterized filamentous phage showed wide host range, reduced the ability of the bacterial cells to produce extracellular polysaccharides (EPS), reduced the motility, slowed the growth rate and significantly reduced the virulence (Ahmad et al., 2014).

The present study was purposed to isolate and identify citrus canker causing bacterial strains in Pakistan. Based on identification, lytic bacteriophages were characterized that are specific to these bacterial strains, to evaluate the sensitivity and biological activity of these phage toward their host under controlled conditions. The attempt provides an evaluation for the selection of effective bacteriophages with a potential to be used as effective biological control agents for field applications.

\section{Materials and Methods}

\section{Survey and Sampling}

Systematic surveys were conducted in major citrus growing regions of Pakistan in March-September 2015-2016. These regions include Sargodha, Bhalwal and Kot Momin in Punjab province, Haripur and Ghazi in Khyber Pakhtunkhwa province, National Agricultural Research Centre (NARC) and Chak Shahzad Farms in Federal Capital Islamabad. Plants were observed for prevalence of citrus canker by observing cankers on leaves and fruits. Samples of infected leaves and fruits were collected from these regions.

\section{Bacterial Isolation}

Leaf samples were first cleaned with autoclaved distilled water and wiped with alcohol soaked cotton while working in a laminar flow hood. Infected tissues on the leaves were removed with a sterilized scalpel and collected in sterilized test tubes. The excised tissues were surface sterilized by applying 75\% ethanol for $30 \mathrm{sec}$. In sterilized Phosphate Buffer Saline (PBS) buffer (Sodium Chloride $8 \mathrm{~g} \mathrm{~L}^{-1}$, Potassium Chloride $0.2 \mathrm{~g} \mathrm{~L}^{-1}$, Disodium Hydrogen Phosphate Potassium $1.44 \mathrm{~g} \mathrm{~L}^{-1}$, Dihydrogen Phosphate $0.24 \mathrm{~g} \mathrm{~L}^{-1}$ ), tissues were ground and suspension was kept for $30 \mathrm{~min}$ at room temperature. Fruits with canker lesion were peeled and $2 \mathrm{~mm}$ area around the lesion on the peel was cut with sterilized scalpel. Sterilization of these tissues was carried out by applying 75\% ethanol for $30 \mathrm{sec}$. These tissues were chopped and soaked in PBS Buffer.

$200 \mu \mathrm{L}$ of both the leaves and fruit PBS suspensions were streaked on the surface of agar plates of Yeast Peptone Glucose Agar medium, YPGA, (Yeast Extract $7 \mathrm{~g} \mathrm{~L}^{-1}$, Buffered Peptone $7 \mathrm{~g} \mathrm{~L}^{-1}$, D-Glucose $7 \mathrm{~g} \mathrm{~L}^{-1}$, Agar $18 \mathrm{~g} \mathrm{~L}^{-1}$ ) Aritua et al. (2006). Samples of each collection were streaked on separate agar plates. Plates were marked with respect to sample IDs and wrapped with parafilm to avoid contamination. These plates were then incubated at $28-30^{\circ} \mathrm{C}$ for 24 to $48 \mathrm{~h}$.

\section{Identification of Bacterial Isolates}

After morphological observation of bacterial isolates on agar plates, biochemical tests including Gram staining, catalase oxidase testing were performed for the screening and differentiation of bacterial isolates. Isolated bacteria were further subjected to biological characterization by leaf infectivity test on citrus leaves and molecular characterization by amplification of pathogenicity related gene and 16S rDNA subsequently.

\section{Bacterial DNA Isolation}

DNA from the leaf infectivity test positive bacterial isolates was obtained by following the protocols of Lopez et al. (1999). In brief, $1000 \mu \mathrm{L}$ of an overnight bacterial culture in YPG broth with Optical Density $\left(\mathrm{OD}_{600}\right)$ of 0.8 was centrifuged at $10,000 \mathrm{xg}$ for 10 minutes. The supernatant was discarded and the pellet resuspended in $500 \mu \mathrm{L}$ extraction buffer (Tris- $\mathrm{HCl} \mathrm{pH} 7.5200 \mathrm{mM}, \mathrm{NaCl} 250 \mathrm{mM}$, EDTA $25 \mathrm{mM}$, SDS 0.5\%, PVP 2\%). The mixture was vortexed and left for one hour at room temperature with continuous shaking. The lysate was centrifuged at $8000 \mathrm{x} \mathrm{g}$ for $5 \mathrm{~min}$. A $450 \mu \mathrm{L}$ supernatant sample was placed in new Eppendorf tube and an equal volume of Isopropanol was added and mixed. The mixture was left for one hour at room temperature, then centrifuged at $13,000 \mathrm{x}$ g for $10 \mathrm{~min}$. The supernatant was discarded and the pellet was air dried, then resuspended in $50 \mu \mathrm{L}$ TE Buffer (Tris- $\mathrm{HCl} 10 \mathrm{mM}$, EDTA $1 \mathrm{mM})$. DNA was quantified usng a nano-drop spectrophotometer (Colibri microvolume) to define the absorbance 260:280 ratios of the DNA samples. Purified DNA was stored at $-20^{\circ} \mathrm{C}$ for further processing. 


\section{PCR Amplification}

DNA amplifications were performed using two pairs of primers to detect a pathogenicity gene and to differentiate strains. The first: J-pth 1(5'CTTCAACTCAAACGCCGGA-3') and J-pth2 (5'CATCGCGCTGTTCGGGAG-3') to amplify a 197 bp fragment for detection of a pathogenicity gene described by Cubero and Graham (2005); J-Rxg (5'GCGTTGAGGCTGAGACATG-3') and J-RXc2 (5'CAAGTTGCCTCGGAGCTATC-3') amplified a 179 bp fragment to detect the atypical strains $\mathrm{A}^{*}$ and $\mathrm{A}^{\mathrm{w}}$, For both the amplification reactions, a reaction mixture of $25 \mu \mathrm{L}$ was used. Reactions were carried out in an Applied Biosystems, 9700 thermal cycler. Each $25 \mu \mathrm{L}$ mixture contained reaction buffer, dNTPs, $25 \mathrm{mM} \mathrm{MgCl}$, Taq polymerase and primers (Axygen Biosciences). Thermal cycling included denaturation at $95^{\circ} \mathrm{C}$ for $5 \mathrm{~min}$., followed by 40 cycles of $95^{\circ} \mathrm{C}$ for $30 \mathrm{~s}, 58^{\circ} \mathrm{C}$ for $30 \mathrm{~s}, 72^{\circ} \mathrm{C}$ for $45 \mathrm{~s}$ and a final step at $72^{\circ} \mathrm{C}$ for $10 \mathrm{~min}$. Amplified products were detected following electrophoresis in $1.2 \%$ agarose gels in $1 \mathrm{X}$ TBE buffer for 1 hour at $100 \mathrm{~V}$ by VWR $300 \mathrm{~V}$ power source and visualized in Gel-Doc Analyzer (Genosens 15600, Clinx Science Instruments Co., Ltd).

The 16S analysis was performed by custom sequencing a $1500 \mathrm{bp}$ fragment of $16 \mathrm{~S}$ rRNA gene that was amplified using universal forward 27F (5'CTTCAACTCAAACGCCGGA-3') and reverse primers 1492R (5'-CATCGCGCTGTTCGGGAG-3') (Lane et al., 1991). Amplified 16S rDNA were purified using a Spinklean Gel Extraction Kit (K511), with samples sent for custom sequencing to Macrogen Inc. Korea.

\section{Phylogenetic Analysis}

The phylogenetic analysis of four bacterial strains SNHXc1, SNHXc2, SNHXc4 and SNHXc6 was performed using partial sequences of $16 \mathrm{~S}$ rRNA gene obtained through custom sequencing. The sequenced fragment of $16 \mathrm{~S}$ rRNA gene assembled and edited using EzEditor software (Jeon $e t$ al., 2014) the genetic similarity of the strains was determined using EzTaxon server (http://www.ezbiocloud.net/eztaxon) (Kim et al., 2012) and the Neighbor-joining phylogenetic tree was generated using MEGA-6 (Tamura et al., 2013).

\section{Citrus Leaf Infectivity Test}

Infectivity was performed on fully expanded but immature kinnow leaves. In a laminar flow hood, leaves were cleaned with $1 \%$ sodium hypochlorite solution. Leaves were then placed on filter paper discs in petri dishes. Each leaf was pricked once on the left, and once on the right side of the primary vein on the abaxial side, with a sterilized needle. Then $100 \mu \mathrm{L}$ of the overnight bacterial culture broth was inoculated on the right side punctures of each leaf. Sterile distilled water was added to the punctures in the left side as a negative control. The petri dishes were marked and placed in a polythene bag for the enhancement of infection in an incubator at $28-30^{\circ} \mathrm{C}$ for 3 to 4 weeks. They were checked daily for appearance of symptoms.

\section{Bacteriophage Isolation}

Samples of approximately $50 \mathrm{~g}$ of soil from the upper $10 \mathrm{~cm}$ of dirt were collected from beneath the trees showing typical canker lesions. For each sample, $50 \mathrm{~mL}$ YPG Nutrient broth medium was prepared in $250 \mathrm{~mL}$ flask and supplemented with $2.5 \mathrm{~g}$ anhydrous $\mathrm{CaCO}_{3} .500 \mu \mathrm{L}$ of the overnight broth cultures was taken as an indicator bacteria and mixed in flasks that contained $\mathrm{YPG}^{-\mathrm{CaCO}_{3}}$ broth medium. Canker lesions on the infected leaves were cut with a sterilized scalpel, chopped and mixed in the flask. Similarly, $10 \mathrm{~g}$ of soil was carefully mixed in flask. All flasks were incubated at $28-30^{\circ} \mathrm{C}$ for $24 \mathrm{~h}$.

Approximately $1 \mathrm{~mL}$ of suspension media from each incubated flask was pipetted into an sterilized Eppendorf tube. The tubes were centrifuged at $16,000 \mathrm{x} \mathrm{g}$ for $5 \mathrm{~min}$. Supernatant from each tube was then passed through a 0.22 $\mu \mathrm{m}$ pore size syringe filter (Sartorius Inc.) to remove any bacteria and collected in new sterilized Eppendorf tube. Then $100 \mu \mathrm{L}$ aliquots of exponential-phase bacterial suspension from each bacterial strain was poured in the center of an empty petri plate followed by addition of just enough warm $\left(45-50^{\circ} \mathrm{C}\right)$ YPGA medium to cover the bottom of the plate. After solidification, 10 to $20 \mu \mathrm{L}$ of phage suspension was dropped on the agar surface. Plates were then incubated for $24 \mathrm{~h}$ at $28-30^{\circ} \mathrm{C}$.

\section{Activity of Phages in In vitro Cultures}

Activity of phages in broth cultures was determined by inoculating $10 \mathrm{~mL}$ of phage suspension in actively growing bacterial cells in broth test tubes. Cultures were prepared by inoculation of identified bacterial cultures from this study (SNHXc1, SNhXc2, SNHXc4, SNHXc6 in YPG broth in 4 test tubes. Test tubes were incubated at $30^{\circ} \mathrm{C}$. After 6 hours, when $\mathrm{OD}_{600}$ reached to approximately $0.5\left(10^{6} \mathrm{CFU} / \mathrm{mL}\right)$, phage suspensions were applied with MOI of 0.1 in 3 test tubes for HXcf1, HXcf2 and HXcf3, while bacterial culture in one test tube was not treated with any phage suspension and considered as control. These tubes were incubated at $28-30^{\circ} \mathrm{C}$ for $24 \mathrm{~h}$ and $\mathrm{OD}_{600}$ values were taken after every 6 h.

\section{Bacterial Sensitivity Evaluation}

The sensitivity of bacterial strains to individual phages was evaluated a soft agar overlay method. Soft YPGA medium was prepared with $0.4 \%$ of agar. $100 \mu \mathrm{L}$ of each exponential phase bacterial culture was mixed with $100 \mu \mathrm{L}$ of phage suspension in a sterilized test tube and $10 \mathrm{~mL}$ of soft agar 
was added to this mixture. After gentle mixing, the mixture was poured upon a previously prepared hard agar base in a petri dish and swirled gently to spread the soft agar evenly on hard agar surface. These plates were left to solidify then placed in incubator for $24 \mathrm{~h}$ at $28-30^{\circ} \mathrm{C}$.

\section{Effect of Bacteriophages on Bacterial Virulence}

Effect of bacteriophages on bacterial virulence was determined on detached leaves of citrus. Leaves were soaked in $1 \%$ sodium hypochlorite solution and again dipped in $70 \%$ ethanol solution for disinfection. Previously sterilized filter paper discs were placed in each sterilized petri plate ( $90 \mathrm{~mm}$ diameter). 4 pricks were made, 2 on both sides of midrib on the abaxial side of each leaf. About 10 $\mu \mathrm{L}$ of the overnight bacterial culture was applied at all the 4 puncture sites. Petri plates were covered in a polythene bag and placed in incubator at $30^{\circ} \mathrm{C}$. After $12 \mathrm{~h}$, plates were again brought to laminar flow hood and $10 \mu \mathrm{L}$ of the phage suspension was applied only on the right side pricks of each leaf. Left side pricks were left as control. The petri plates were kept for further incubation at $28-30^{\circ} \mathrm{C}$ for 4 weeks.

\section{Results}

\section{Bacterial Isolation}

Fifteen distinct bacterial isolates were identified from the infected leaves and fruits of citrus plants that fit characteristics of Xanthomonas sp. regarding morphology and biochemical tests. These bacterial isolates produced round, off white to creamy yellow and mucoid colonies. The origin, source, morphological and biochemical screening results of selected bacterial isolated for further investigations are reported in Table 1.

\section{Molecular Characterization}

The amplified product of 197 bp DNA fragment of the nuclear localization signal in virulence gene was obtained using the primer pair J-pth1 and J-pth2. The specific amplification was obtained only for four bacterial isolates, including SNXc1, SNXc2, SNXc4 and SNXc6 as shown in Fig. 1. The primer pair, J-Rxg and J-RXc2 used to differentiate atypical strains on the basis of differences in intergenic transcribed spacer (ITS) regions of $16 \mathrm{~S}$ and $23 \mathrm{~S}$ rDNAs. However, no atypical strain amplicons were found. The 1500 bp amplicon (Fig. 2) of $16 S$ rRNA gene was custom sequences and analyzed on EzTaxon server by BLAST to find the sequence homology. The sequence analysis of PCR product showed maximum similarity with Enterobacter cowanii strain. In total nucleotide sequence for $16 \mathrm{~S}$ rDNA product for four bacterial samples were determined originating from different areas in Pakistan (Fig. 3 ). The nucleotide identities of 16SrRNA gene sequence of bacterial strains determined in this study has been compared with each other and with others published GenBank

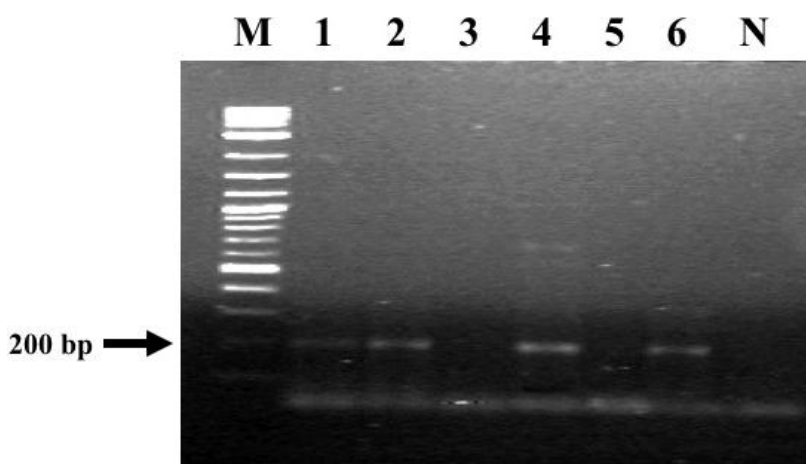

Fig. 1: Amplification of PthA Virulence gene in Citrus Canker Causing Bacteria (SNHxc1-6). Lane 1-6 are SNHXc1 to SNHXc6 respectively. Lane M is $1 \mathrm{~kb}$ DNA marker (New England Biolab) and Lane $\mathrm{N}$ is -ve control

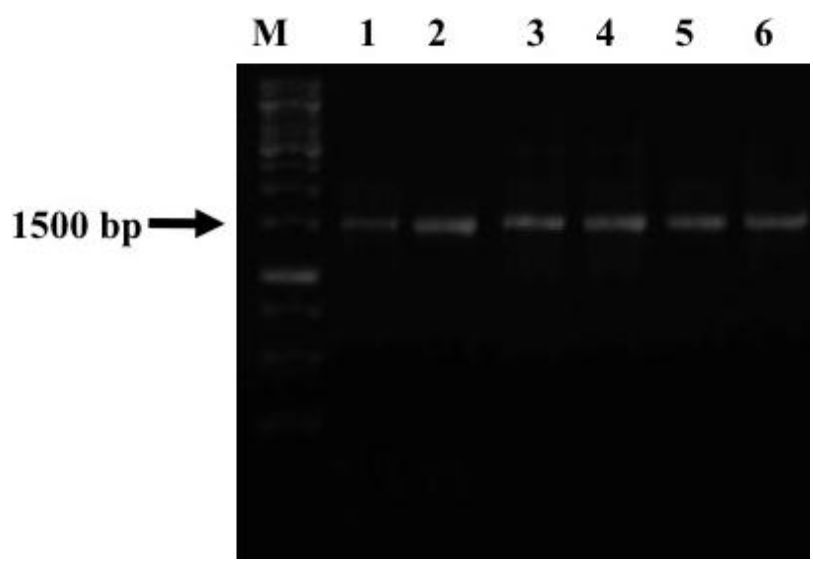

Fig. 2: Amplification of partial $16 S \mathrm{r} R N A$ gene from Citrus Canker Causing Bacteria (SNHxc1-6). Lane 1-6 are HXc1 to HXc6 respectively. Lane M is $1 \mathrm{~kb}$ DNA marker (New England Biolab)

database. Original strain identities and characteristics of those bacteria causing disease in citrus in Pakistan from this study are listed in Table 1.

\section{Infectivity Test}

In detached leaf infectivity tests, symptoms appeared on pricking sites 5 days post infection. After 2 weeks, lesions became enlarged and turned from tan to brown. Typical canker symptoms of raised and spongy lesions were developed after 3 weeks of infection. Canker symptoms appeared for HXc1, HXc2, HXc4 and HXc6. For HXC3 and $\mathrm{HXc5}$, mild brownish color at puncture sites developed which could not be described as canker like lesion. Canker symptoms appeared at the right side of leaf abaxial surface where bacterial broth cultures were inoculated while on the left side no cankers were produce and no other symptoms. Citrus leaf infectivity test results of bacterial culture SNHXc6 are shown in Fig. 4. 
Table 1: The origin, source, growth and biochemical characteristics of bacterial strains

\begin{tabular}{lllllll}
\hline Strains ID & Origin & Source & Growth on YPGA & Gram's Staining & Catalase Test & Oxidase Test \\
\hline SNXc1 & Hazara KPK & Leaves & +++ & - & + & - \\
SNXc2 & Kot Momin Punjab & Fruit & ++ & - & + & - \\
SNXc3 & Kot Momin Punjab & Fruit & +++ & - & + & - \\
SNXc4 & Hazara, KPK & Leaves & +++ & - & + & - \\
SNXc5 & Hazara, KPK & Leaves & +++ & - & + & - \\
SNXc6 & Islamabad (NARC) & Leaves & +++ & - & + & - \\
SNXc7 & Islamabad (NARC) & Leaves & ++ & - & + & - \\
SNXc8 & Islamabad (NARC) & Leaves & ++ & - & + & - \\
SNXc9 & Islamabad (NARC) & Fruit & + & - & + & - \\
SNXc10 & Islamabad (Chak Shahzad Farms) & Leaves & + & - & + & - \\
SNXc11 & Sargodha, Punjab & Fruit & ++ & - & + & - \\
SNXc12 & Sargodha, Punjab & Leaves & ++ & + & + & - \\
SNXc13 & Bhalwal, Punjab & Leaves & + & + & + & + \\
SNXc14 & Bhalwal, Punjab & Leaves & + & + & + & + \\
SNXc15 & Bhalwal, Punjab & Leaves & + & + & + \\
\hline
\end{tabular}

++ , strongly positive, active bacterial growth; ++ , for Normal growth rate; + , for mild and delayed growth;,- negative

\section{Bacteriophage Isolation}

A total of 30 soil samples were screened for isolation of bacteriophages against already characterized bacterial strains for pathogenicity on citrus and other morphological, biochemical and molecular tests in this study. Three bacteriophage isolations were selected on the basis of produced clear zones on YPGA plates, with restricted bacterial growth. These phages were further purified and propagated by mass streaking to a final concentration of $10^{7}$ PFU (plaque forming unit)/mL and named HXcf1, HXcf2 and HXcf3.

\section{Bacterial Sensitivity Evaluation}

Bacteriophages were checked by both spot assay and plaque formation. Out of the 15 bacterial isolates, 5 were sensitive to one or two bacteriophages. Intensity of the bactericidal effect of phages and sensitivity of bacterial strains were evaluated by observing the spots and plaques produced on bacterial lawn. The selected bacteriophages HXcf1 produced clear, round and homogenous plaques with an average size of $5 \mathrm{~mm}$. However, the sensitivity pattern was different for different phages against different bacteria. Five bacterial isolates out of 15 were sensitive to HXcf1. HXcf1 had bactericidal effect against SNHXc1, SNHXc2, SNHXc4, SNHXc6 and SNHXc10. HXcf2 was effective only against SNHXc6 and SNHXc2 while HXcf3 produced zones on SNHXc1, SNHXc4 and SNHXc6 bacterial lawns.

\section{Activity of Phages in Broth Cultures}

Activity of phages in broth cultures was observed for bacterial strain HXc6 that was most aggressive in causing infection. The HXcfland HXcf3 phages caused complete lysis of bacterial cells. After $24 \mathrm{~h}$ of incubation, debris of lysed cells settled without any new growth. No effect was observed for HXcf2 as it was same when compared to nonphage treated culture. The $\mathrm{OD}_{600}$ values were taken for every culture after every $6 \mathrm{~h}$ upto $24 \mathrm{~h}$ (Fig. 5 and 6).

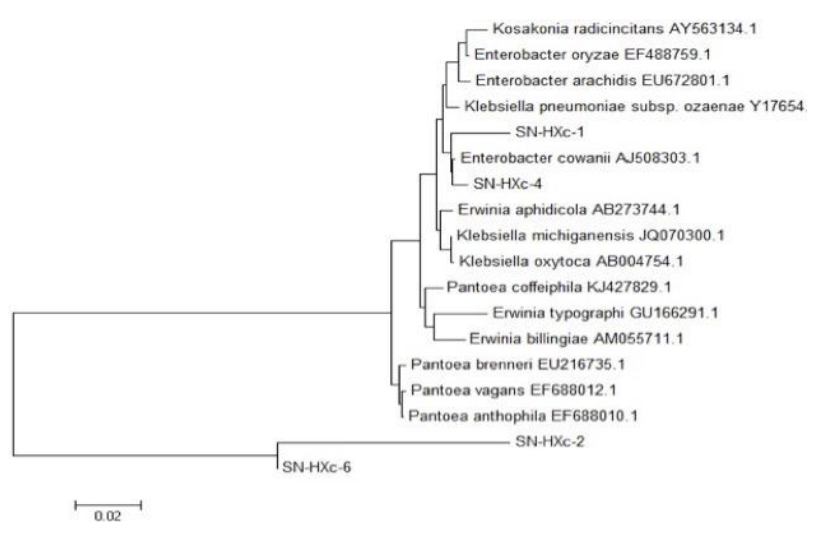

Fig. 3: Neighbor-joining tree representing phylogenetic relationships on the basis of partial $16 \mathrm{~S}$ rDNA of Citrus canker causing bacterial strains from Pakistan and other related sequences selected via BLAST search. The phylogenetic tree showed interrelationship of strains SNHXc1, SNHXc-2, SNHXc4 and SNHXNc6 with the members of genus Kosakonia and other closely related genera. The tree is based on pairwise comparisons using the Jukes-Cantor parameter on nucleotide sequences. Upper and lower branch points show bootstrap values (1,000 replicates) supporting a particular phylogenetic group. The scale bar represents nucleotide substitutions per site

Bootstrap values (>60\%) expressed as percentages of 1000 replications, are shown at the branch points. The scale bar represents nucleotide substitutions per site

\section{Effect of Phages on Bacterial Virulence}

After 2 weeks post infection, canker symptoms of raised, spongy and dark brownish lesions appeared only at the sites where bacterial culture was applied. The most effective treatment was from HXcf1. For HXcf1, mild chlorosis occurred just around the pricking site that was quite differentiable from the left side's lesions. After 3 weeks 

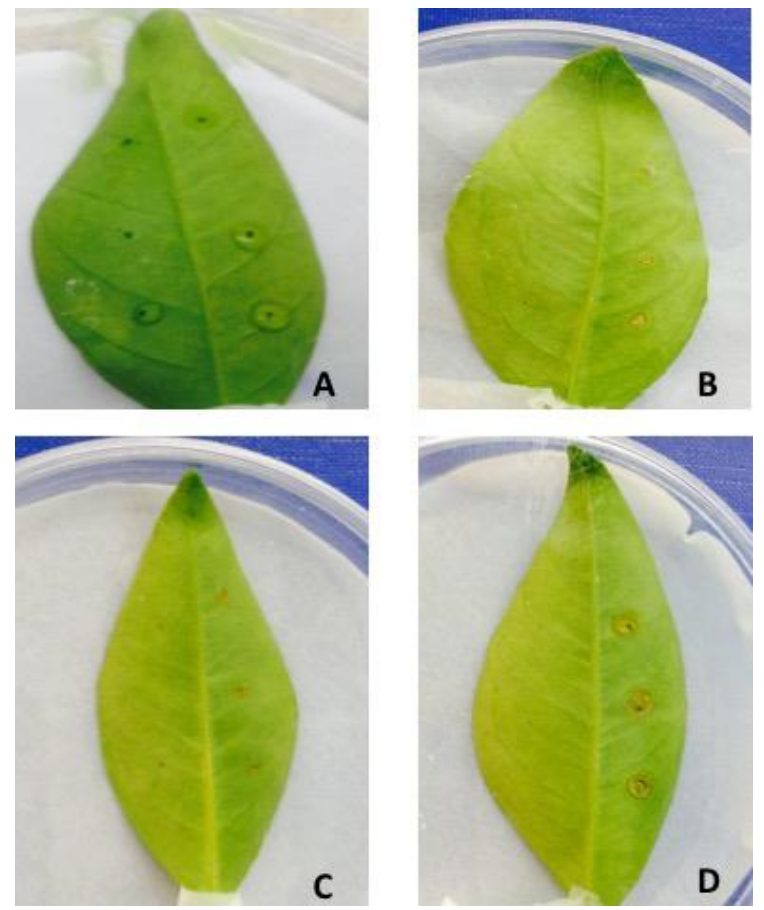

Fig. 4: Leaf Infectivity test of Citrus Canker Causing Bacteria (SNHXc6) on citrus leaves

A: A. One week post inoculation (wpi); B: Two wpi; C: 3 wpi; D: 4 wpi

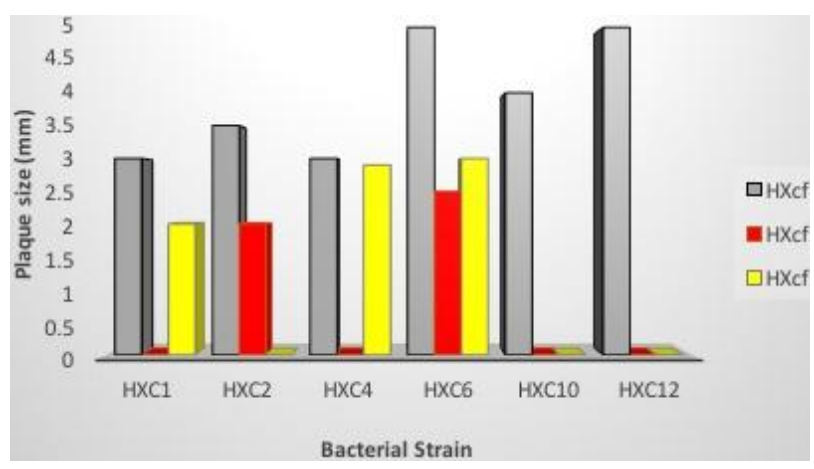

Fig. 5: Growth of Bacteriophages (in terms of Plaques produced) on different Bacterial Lawns

All strains are sensitive to HXcf1 (as shown by grey color), HXcf2 is effective against Hxc2 and 6 (Red color), HXcf3 forms plaques on HXcf1, 4 and 6 (Yellow color)

post-infection, lesions of left side increased in size up to 7 $\mathrm{mm}$ but HXcf1 treated did not exceed $2.5 \mathrm{~mm}$ on right side. (Fig. 7). HXcf2 treatment had no effect on bacterial virulence. Lesions produced on both sides of leaf were same for HXcf2. HXcf3 also affected the infection but its effect was relatively less than HXcf1. Although erumpent lesions were produced on both sides of leaf but $\mathrm{HXcf} 3$ treated inoculated lesions were comparatively small in size. Size of the lesions was $6.5 \mathrm{~mm}$ on left side and $3.5 \mathrm{~mm}$ on right side.
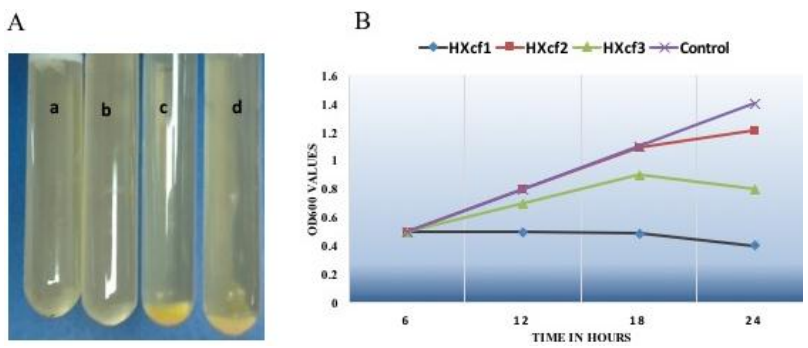

Fig. 6: Activity of Phages in Broth Bacterial Cultures of SNHXc6

A. shows the bacterial cultures in Tubes. a) is not treated with any phage, $b$ is treated with Bacteriophage $\mathrm{HXcfl} 1$, c) is treated with Bacteriophage HXcf2 and d) with Bacteriophage HXcf3

B. shows the activity of Phages in Broth Culture after 24 hours. Following incubation the debris of lysed cells were settled down in test tubes. There was no effect observed for $\mathrm{HXcf} 2$
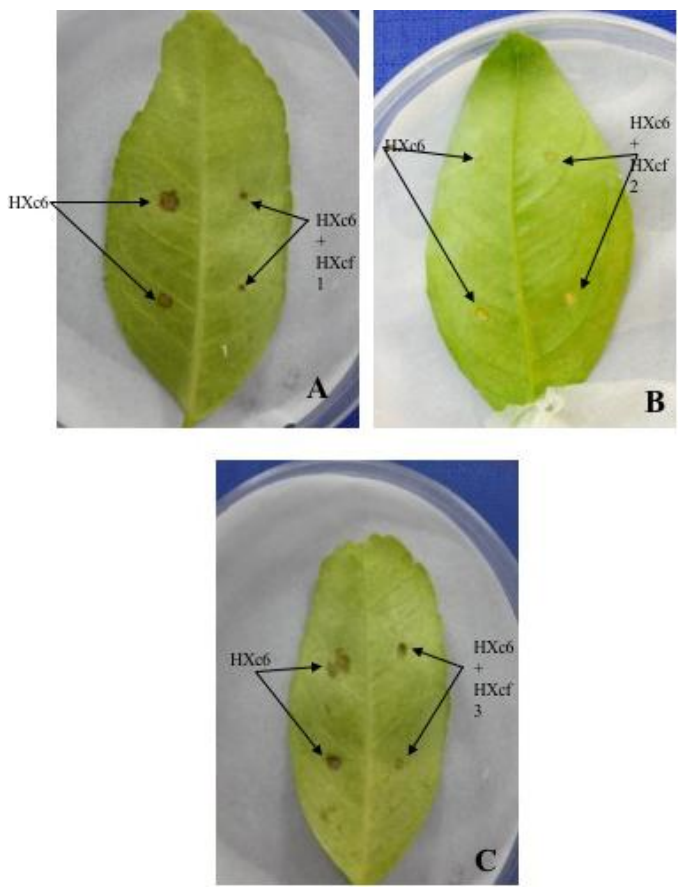

Fig. 7: Effect of Bacteriophages on Bacterial Virulence A: Bacteriophage HXcf1 Treatment with Bacterial Strain SNHXc6, B: Bacteriophage HXcf2 Treatment with Bacterial Strain SNHXc6, C: Bacteriophage HXcf3 Treatment with Bacterial Strain SNHXc6

\section{Discussion}

Pakistan has a climate that is conducive to the production of all fruits of marketable importance. Among these, citrus is the largest in terms of production and export (PHDEB, 2008). However, the overall warm climate in citrus production areas favors the growth of phytopathogens and diseases. A number of diseases caused by bacteria are economically important. The citrus industry of Pakistan is heavily infested with citrus canker, one of the deadliest bacterial-plant diseases. In some parts of world including 
America and Brazil, this disease is controlled through burning and uprooting of infected groves (Gottwald et al., 2002) but in developing countries including Pakistan, where infection is disseminated to most of the citrus groves of the region, such eradication is not feasible. Other core strategies to control this disease include use of chemicals and antibiotics, but generally bacterial outbreaks are difficult to limit, due to development of resistance against the target pathogen and scarcity of effective bactericides (Balogh et al., 2010). Aminoglycoside application reported to provide systemic acquired resistance in plants against bacterial pathogens but for the causative agent of citrus canker, these are unable to produce any consequential outcome (Jones et al., 2012). Others have considered controlling phytopathogens using biological treatments such as phages. About $4-50 \%$ bacteria produced everyday are lysed by bacteriophages, they also maintain the geochemical cycle globally and known to reserve the greatest genetic variety. It is astonishing, that they were not recognized even after the initiation of some significant bacteriological work in Europe and America in 1880s (Ceyssens, 2009). Phage therapy has also been used for epidemiology of pathogens associated with human disease (Zaczek et al., 2015). Biological control of citrus canker with bacteriophages is in trials in USA while the green house and nursery experiments have shown promising results (Balogh et al., 2008). The study presented here is the first report about specific phages against bacteria causing disease in citrus in Pakistan. The chemical and biochemical tests conducted for the identification of isolated bacterial strains demonstrated that their features Gram negative, catalase positive and oxidase negative resembles to the plant pathogenic bacteria associated with citrus canker disease (Vernière et al., 1998). The bacterial strains were characterized and verified for their disease potential by amplification of pathogenicity gene and disease potential on citrus leaves. The selected bacteria with disease potential were accessed for molecular characterization. Amplification was performed for virulence gene PthA. The results were positive for the isolates that were sampled and processed in March and April as shown in Fig. 1. The samples that were obtained for bacterial isolation in July and August, did not reveal amplification of virulence gene from their DNA. These findings show that the ideal sampling time for citrus canker causing pathogenic bacteria is before the onset of summer. No amplification occurred for J-Rxg and J-RXc2 primers that confirmed the disease prevalence in Pakistan is mainly due to presence of type A strains as described in (EPPO, 2005). The results obtained from infectivity test were positive only for those strains that were also positive for presence of virulence gene PthA. Bacteria grow rapidly on YPG agar plates within 24 to $36 \mathrm{~h}$ but the incubation period for infectivity test extends to 3 to 4 weeks. In first 2 to 3 days of infection, mild chlorosis is observed on all the leaves. But after 1 week of infection, lesions formed on the pricking sides increased in size only for the strains that possessed the virulence genes.
There are number of different type of bacterial spp. which cause many diseases in citrus. The phylogenetic analysis of partial 16S rRNA gene of the test bacteria revealed closest relatives from the Enterobacteriaceae family based on the clustering. For phylogenetic tree construction, the bacterial strains after the similarity search on BLAST were selected for relatedness on the basis of their origin and pathogenesis in plants. However, it is known that the classification of the bacterial strains in the Enterobacter family is not clear, thus indicating the limitation of $16 \mathrm{~S}$ resolution for the species classification for the test strains. On the basis of partial $16 \mathrm{~S}$ rDNA a neighbor joining phylogenetic tree was constructed, the bacterial strains SNHXc1 and SNHXc4 were closely related to the strain Enterobacter cowanii AJ5083031 also named as Kosakonia cowanii, which is plant pathogen found to cause disease in a native wild plant species found in the forest in Brazil, known to cause bacterial spot on Mabea fistulifera (Furtado et al., 2012). Whereas, the two other strains SNHXc-2 and SN-HXc6 made an out group to the rest of the strains and did not show relatedness to any other bacteria in phylogenetic tree thus indicating less genetic difference between them. This is the first report of characterization of bacterial strains causing citrus canker disease in Pakistan. Other citrus canker disease incidence reports on citrus grown in Pakistan have only used phenotypic and morphological disease symptoms on plants for suspected pathogen (Sahi et al., 2007; Burhan et al., 2007).

Three phages that were identified and studied HXcf1, HXcf2 and HXcf3 showed different abilities to limit infections of specific bacterial strains. HXcf1 was found with most aggressive bactericidal effect. HXcf1 has been found to attack all the virulent bacterial strains. These phages were also tested for their effect in broth cultures. Promising results were observed for $\mathrm{HXcf1}$ and $\mathrm{HXcf} 2$ for their effect on bacterial virulence. Phage suspensions of HXcf1 and HXcf2, when applied to the plant leaves that were previously inoculated with the most aggressive bacterial strain HXc6, the two phages significantly reduced the virulence. Similar results obtained for $X$. axonopodis $\mathrm{pv}$. citri phages that were isolated in Japan (Ahmad et al., 2014).

Although HXcf1 and HXcf3 can effectively lyse bacterial cells that cause citrus canker, use of these phages as biological control agents is still a challenge. That phages isolated from plant tissues were more effective for biological control than phages from soil (Balogh et al., 2008). The phages isolated from soil tend to have broader host range but several factors such as diffusion of phages through heterogeneous soil matrix, biofilm formation, soil particles that trap phages irreversibly and low soil $\mathrm{pH}$ could deliberately affect the use of phages for control of diseases in rhizosphere (Gašič et al., 2011). The way forward is the development of formulation whereby phages isolated from soil would be able to persist in harsh environment of phylosphere. The HXcf1 and HXcf2 that are from 
rhizosphere have shown their bactericidal effect on agar plates and broth cultures. This shows that these two phages could be used in wet preparations that will be more favorable for phages to survive and also with an ease of application on citrus plants.

\section{Acknowledgements}

The authors are highly thankful to International Foundation for Science (IFS) for providing research grant (IFS grant D/5879-1) to conduct this research.

\section{References}

Ahmad, A.A., A. Askora, T. Kawasaki, M. Fujie and T. Yamada, 2014. The filamentous phage $\mathrm{XacF} 1$ causes loss of virulence in Xanthomonas axonopodis pv. citri, the causative agent of citrus canker disease. Front. Microbiol., 2: 1-11

Aritua, V., A. Nanyonjo, F. Kumakech and W. Tushemereirwe, 2006. RepPCR reveals a high genetic homogeneity among Ugandan isolates of Xanthomonas campestris pv. musacearum. Afr. J. Biotechnol., 6: 179-183

Balogh, B., B.I. Canteros., R.E. Stall and J.B. Jones, 2008. Control of citrus canker and citrus bacterial spot with bacteriophages. Plant Dis., 92 1048-1052

Balogh B., J.B. Jones, F.B. Iriarte and M.T. Momol, 2010. Phage therapy for plant disease control. Curr. Pharm. Biotechnol., 11: 48-57

Behlau, F., B.I. Canteros, G.V. Minsavage, J.B. Jones and J.H. Graham, 2011. Molecular characterization of copper resistance genes from Xanthomonas citri subsp. citri and Xanthomonas alfalfae subsp. citrumelonis. Appl. Environ. Microbiol., 77: 4089-4096

Burhan, M., N.A. Chaudhary, M. Ishfaq and M. Sarwar, 2007. Incidence of citrus canker (Xanthomonas compestris pv. Citri) on orange cultivars in nursery. Int. J. Agric. Biol., 9: 533-534

Canteros, B.I., 2010. Management and characterization of plasmid-encoded copper resistance in Xanthomonas axonopodis pv. citri. In: $12^{\text {th }}$ International Conference on Plant Pathogenic Bacteria, p: 145 Reunion Island, France

Ceyssens, P., 2009. Isolation and Characterization of Lytic Bacteriophages Infecting Pseudomonas. Doctoral Dissertation, KU Leuven

Cubero, J. and J.H. Graham, 2005. Quantitative real-time polymerase chain reaction for bacterial enumeration and allelic discrimination to differentiate Xanthomonas strains on citrus. Phytopathology, 95: $1333-1340$

EPPO, 2005. Xanthomonas axonopodis pv. citri. EPPO Bull., 35: 289-294

Fujiwara, A., M. Fujisawa, R. Hamasaki, T. Kawasakt, M. Fujie and T. Yamada, 2011. Biocontrol of Ralstonia solanacearum by Treatment with lytic bacteriophages. Appl. Environ. Microbiol., 77: 4155-4162

Furtado, G.Q., L.M.S. Guimaraes, D.O. Lisboa, G.P. Cavalcante, D.A.A Arriel, A.C. Alfenas and J.R. Oliveira, 2012. First report of Enterobacter cowanii, causing bacterial spot on Mabea fistulifera, a native forest species in Brazil. Plant Dis., 96: 1576-1576

Gašič, K., M.M. Ivanović, M. Ignjatov, A. Calić and A. Obradović, 2011. Isolation and characterization of Xanthomonas euvesicatoria bacteriophages. J. Plant Pathol., 39: 415-423
Gottwald, T.R., J.H. Graham and T.S. Schubert, 2002. Citrus Canker: the Pathogen and its Impact; Plant Health Progress. Available at: http://www.plantmanagementnetwork.org/php/>. (Accessed on 28 November 2016)

Jeon, Y.S., K. Lee, S.C. Park, B.S. Kim, Y.J. Cho, S.M. Ha and J. Chun, 2014. EzEditor: a versatile sequence alignment editor for both rRNA- and protein-coding genes. Int. J. Syst. Evol. Microbiol., 64 689-691

Jones, J.B., G.E. Vallad, F.B. Iriarte, A. Obradovic, M.H. Wernsing, L.E. Jackson, B. Balogh, C.J. Hong and M.T. Momol, 2012 Considerations for using bacteriophages for plant disease control. Bacteriophage, 2: 208-214

Kim, O.S., Y.J. Cho, K. Lee, S.H. Yoon, M. Kim, Y. Na, S.C. Park, Y.S. Jeon, J.H. Lee, H. Yi, S. Won and J. Chun, 2012. Introducing EZTAXON-E: a prokaryotic 16S rRNA gene sequence database with phylotypes that represent uncultured species. Int. J. Syst. Evol. Microbiol., 62: 716-721

Lane, D.J., 1991. 16S/23S rRNA sequencing. In: Nucleic Acid Techniques in Bacterial Systematics, pp: 115-175. Stackebrandt, E. and M Goodfellow (eds.). John Wiley and Sons, New York, USA

Lim, J.A., S. Jee, D.H. Lee, E. Roh, K. Jung, C. Oh and S. Heu, 2013. Biocontrol of Pectobacterium carotovorum subsp. carotovorum using bacteriophage PP1. J. Microbiol. Biotechnol., 23: 1147-1153

Lopez, M., P. Llop, P. Caruso, J. Cubero and C. Morente, 1999. A simple extraction procedure for efficient routine detection of pathogenic bacteria in plant material by polymerase chain reaction. J. Microbiol. Methods, 37: 23-31

PHDEB, 2008. Pakistan Horticulture Development and Export Board, Citrus Marketing Strategy. Available at http://www.phdec.org.pk/MktStrategies/Citrus.pdf (accessed on Sep. 12, 2016)

Sahi, S.T., M.U. Ghazanfar, M. Afzal, Abdulrasheed and A. Habib, 2007. Incidence of citrus canker disease caused by Xanthomonas Campestris pv. Citri (HASSE) down on kinnow (Citrus reticulata) and its chemotherapy. Pak. J. Bot., 39: 1319-1327

Schnabel, E.L. and A.L. Jones, 2001. Isolation and Characterization of five Erwinia amylovora bacteriophages and assessment of phage resistance in Strains of Erwinia amylovora. Appl. Environ. Microbiol., 67: 59-64

Stall, R.E. and E.L. Civerolo, 1991. Research relating to the recent outbreak of citrus canker in Florida. Annu Rev Phytopathol., 29: 399-420

Tamura, K., G. Stecher, D. Peterson, A. Filipski and S. Kumar, 2013. MEGA6: molecular evolutionary genetics analysis version 6.0. Mol. Biol. Evol., 30: 2725-2729

Uppal, B.N., 1933. Annual Report. Bombay Presidency. Department of Agriculture. Rev. Appl. Mycol., 12: 225-230

Vauterin, L., B. Hoste, K. Kersters and J. Swings, 1995. Reclassification of Xanthomonas. Int. J. Sys. Bacteriol., 45: 472-489

Vernière, C., J.S. Hartung, O. Pruvost, E.L. Civerolo, A.M. Alverez, P. Maestri and J. Luisetti, 1998. Characterization of phenotypically distinct strains of Xanthomonas axonopodis pv. citri from south west Asia. Eur. J. Plant Pathol., 104: 477-487

Wakimoto, S., 1967. Some characteristics of citrus canker bacteria, Xanthomonas citri (Hasse) Dowson, and the related phages isolated from Japan. Ann. Phytopathol. Soc. Jpn., 33: 301-310

Zaczek, M., B. Weber-Dąbrowska and A. Górski, 2015. Phages in global fruit and vegetable industry. J. Appl. Microbiol., 118: 537-556

(Received 22 March 2017; Accepted 05 May 2017) 